\title{
Entrepreneurship Education in SMK Amanah Bangsa, Cikarang: 'Starting-Up a Business is not that Hard'
}

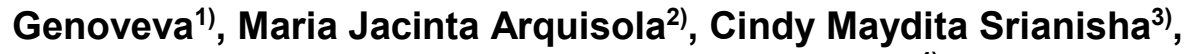 \\ Antonius Whisnu Perdana Widiputra ${ }^{4}$ \\ 1), 2), 3), 4) Faculty of Business, President University \\ 1) genoveva@president.ac.id, 2) mjarquisola@president.ac.id \\ 3) cindymaydita05@gmail.com, ${ }^{4)}$ ant.whisnu@president.ac.id
}

\begin{abstract}
The government's attention to vocational graduates has recently become a hot issue and various programs have been carried out by the government to improve the quality of vocational graduates, therefore they can compete. However, the BPS data in 2018 shows that the number of unemployed graduates from vocational school (SMK) is the highest, namely $11.24 \%$, while Senior High School (SMA) is $7.95 \%$ and Junior High School (SMP) is $4.80 \%$. Based on the problem, Study Program of Management, Faculty of Business, President University implemented a community service program that supports government policy, namely by providing Entrepreneurship Education to students of Amanah Bangsa Informatics Vocational School, Cikarang. With this entrepreneurship education, SMK graduates are expected to start a business as an alternative after graduating later. Entrepreneurship education is given in the form of seminars for Class XII students conducted by lecturers and students. In addition to providing lecture material on Entrepreneurship, students who have carried out business projects also share their experiences while opening a business, doing business until business liquidation as part of Entrepreneurship Course. The point is that students want to convey that starting a business is easy and has many challenges that are very suitable for millennials, and can apply all our abilities. The event was closed by giving a memento to the Vocational School and certificates to the participants.
\end{abstract}

Keywords: Entrepreneurship Education, Business, Start Up, Vocational School

\begin{abstract}
ABSTRAK
Perhatian pemerintah terhadap Iulusan SMK belakangan ini menjadi isu yang hangat dan berbagai program dilakukan pemerintah untuk menigkatkan kualitas lulusan SMK sehingga dapat bersaing. Namun data BPS tahun 2018 menunjukkan bahwa jumlah pengangguran dari lulusan SMK adalah yang tertinggi yaitu sebesar $11,24 \%$, sementara SMA sebesar 7,95\% dan SMP 4,80\%. Berdasarkan permasalah tersebut Prodi Management, Fakultas Bisnis, Universitas President melaksanakan program kegiatan pengabdian masyarakat yang mendukung kebijakan pemerintah, yaitu dengan memberikan pendidikan kewirausahaan terhadap siswa SMK Informatika Amanah Bangsa, Cikarang. Dengan pendidikan kewirausahaan ini, Iulusan SMK diharapkan dapat memulai bisnis sebagai salah satu alternatif setelah lulus nanti. Pendidikan kewirausahaan ini diberikan dalam bentuk seminar terhadap siswa kelas XII yang dilakukan oleh dosen dan mahasiswa. Selain dalam bentuk pemberian materi mengenai Kewirausahaan oleh dosen, para mahasiswa yang telah melakukan bisnis projek juga memberikan sharing pengalamannya selama membuka bisnis, melakukan bisnis sampai ke likuidasi bisnis sebagai bagian dari mata kuliah Entrepreneurship. Intinya para mahasiswa ingin menyampaikan bahwa memulai bisnis itu mudah dan memiliki banyak tantangan yang sangat cocok untuk generasi milenial, serta dapat mengaplikasikan semua kemampuan kita. Acara ditutup dengan pemberian kenang-kenangan terhadap SMK dan sertifikat kepada peserta.
\end{abstract}

Kata-kata Kunci: Pendidikan Kewirausahaan, Bisnis, Start Up, SMK

\section{INTRODUCTION}

To support the government program that related with graduates of vocational school, researchers carry out Social Community Projects which are one of the agendas in the Entrepreneurship subject, Researchers chose SMK Informatika Amanah Bangsa 
Informatics, located in East Cikarang as the Social Community location due to the distance of the location that is not far from President University, approximately $5.3 \mathrm{~km}$; therefore, we do not spend a lot of time on the trip. Besides that, the underlying reason Researchers chose this school because this school had been cooperation with President University in some of various project.

Besides that, in accordance with the school selected, researchers's social community object were vocational students. The reason behind why researchers chose vocational schools compared to senior high school was because we realized that the possibility of vocational school graduates working after graduated is greater than high school students, because from their vocational school, they had been taught and focused on their respective interests in accounting, IT, and so on, therefore they were better prepared to face the workforce. With the topic of Researchers's social community, namely "Starting Up A Business Is Not That Hard", in line with the prospect of social community object in the future, Researchers wanted to encourage all participants to build their own businesses rather than work for other companies. Researchers also wanted to convince them that building their own business is not as difficult as being thought, also guided them and taught them the steps of how to start a business.

In addition, researchers also supported current government programs which focus on improving the quality of vocational students because the unemployment rate in Indonesia is most contributed by vocational school graduates due to the imbalance of employment demand and supply, also inadequate skills (Ratnasari, 2018). Therefore, Researchers wanted to contribute through the Researchers social community program which enhanced the insight to the participants regarding entrepreneurship and how-to start-up their own businesses to reduce the number of unemployment in Indonesia.

\section{PROBLEM IDENTIFICATION}

The problem of unemployment is inevitable in Indonesia. This can be due to the limited employment, but the number of workers keep increasing overtime, causing the demand and supply are imbalanced. One of the factors that is suspected to be the cause is the lack of Indonesians who want to establish their own businesses or in other words they tend to choose to work with other companies. This is evidenced by the number of Indonesian entrepreneurs which only reached $3.1 \%$, even though other countries in ASEAN such as Malaysia, Singapore, Thailand have reached above 4\%; even in almost all developed countries, the standard is $14 \%$ entrepreneurs (Kuwado, 2018). This is also evidenced by researchers activities on November 29 and 30, 2018, when the participants were asked who wanted to open their own business (entrepreneur) after graduated, but 
none of them raised up their hands. The reasons also vary such as limitation of capital, lack of interest, had no idea yet, and so on.

In addition, the problem of unemployment is also caused by inadequate skills needed in the workforce. BPS data in 2018 shows that the number of unemployed graduates from vocational school (SMK) is the highest, namely $11.24 \%$, while Senior High School (SMA) is $7.95 \%$ and Junior High School (SMP) is $4.80 \%$. Even though their vocational schools are focused on specific field work, the education system is arguably not up to date or in other words, the choice is relatively same every year, even though technological improvement continues to change the dynamics of the world. For example students majoring in automotive who are still learning how to work on carburetors, even though with the development of motorbike technology today many have used injection machines. Not only that, many jobs that were once carried out by humans have now been replaced by machines. If the labors still depend heavily on job vacancies from other companies or in other words do not start their own businesses, then in the future there will be lesser employment offerings and humans will lose to increasingly sophisticated technological developments (Komisi X, 2018).

Based on the problems, Study Program Management, Faculty of Business, University President implemented a community service program that supports government policy, namely by providing Entrepreneurship Education to students of Amanah Bangsa Informatics Vocational School, Cikarang.

\section{METHOD}

\section{a. The Object of Activity}

The object of activity is the students of SMK Informatika Amanah Bangsa, approximately 50 students (from 2 cklasses). Based on the results of our analysis that vocational students have the possibility of working after graduation is greater than high school students, because since their school they have been focused on specific fields that become their provision to work later; we therefore want to encourage the participants, which is SMK Informatika Amanah Bangsa students to build their own business rather than having to depend on existing employment.

\section{b. The Method of Activity}

Social community activities were carried out in a seminar method where the lecturers and students team delivered the materials verbally related to the steps, what departments are needed along with the functions of each department before starting up a business. Social community activities were presented with the concept of fun learning which were completed with game sessions held in the midst of presentation as ice breaking. This was 
so that the participants did not get bored and refreshed their mind so that they could concentrate again on listening to the materials presented by the team. By considering the language limitations of our social community object, therefore, all materials presented were delivered in Indonesia languange.

\section{c. Social Community Model}

This model illustrates that graduates of SMK Amanah Informatika Bangsa have only had a mind set that after graduating, those who do not continue their studies are looking for work (Figure 1). With the provision of entrepreneurship education, it is expected that they can change their mind set, from looking for work to creating employment opportunities for other people. With this program they are expected to have another alternative after graduation, looking for work and starting a business.

This activity will be more effective if it is designed better, namely with a more comprehensive and sustainable number of meetings and activities. The SMK can also enter entrepreneurship education as part of the curriculum.

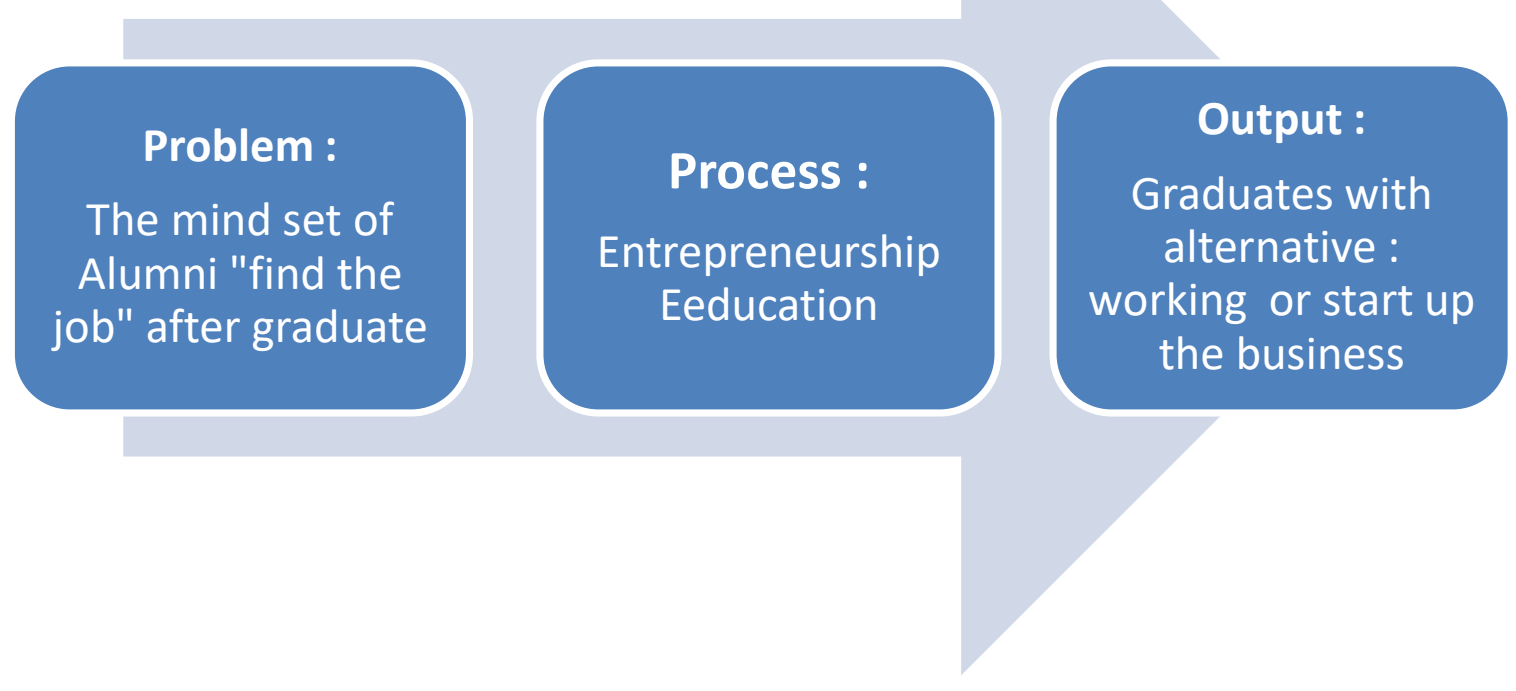

Figure 1. Social Community Model

\section{Social Community Activites}

Vocational High School is education at the secondary education level which prioritizes the development of the ability of students to be able to carry out work in certain fields. At this level students are prepared to enter the workforce and develop professional attitudes. In accordance with its form, the vocational high school curriculum 
organizes educational programs tailored to the needs of the existing workforce. Students can also choose the fields or skills they wish to pursue in accordance with their own talents and interests (Government Regulation Number 29 of 1990). Ministry of Education and Culture Vocational Development Director Mustaghfirin Amin at Tirto.id said the prospect of Vocational graduates is dedicated to working in fields that have been chosen to pursue or become entrepreneurs (Putri, 2017).

An entrepreneur is a person who is able to create new jobs and is able to create added value through new ideas or new inventions into a successful innovation (Rusu, Isac, Curetanu, \& Csorba, 2012). In this modern era, the role of entrepreneurs is very important in reducing unemployment in Indonesia because the presence of new entrepreneurs opens up more jobs so that the supply of employment opportunities also increases. In addition, the increase in the number of Indonesian entrepreneurs will also reduce the level of dependence of job seekers on available employment and tends to be increasingly limited (Cahyu, 2017).

According to Smith \& Reid (2000), in building a business, an entrepreneur will usually start from the formation of a team that will run the whole business, consisting of: CEO (leader who will manage the entire company), Human Resource (unit that manages the human resources), Finance (the unit that manages the company's financial ), Production (regulating activities related to production), marketing (market and promoting company products as well as increasing brand recognition).

Overall, researcher has some main activities during the social community, which were

\section{a. Speech}

It was divided by two, which were the speech of the school representative and speech from President University representative as well. This speech was as a symbol for the beginning of social community activities, intended to be a good start of our activity and it was also hoped that through the opening speeches it would encourage the participants to listen to the materials to be delivered.

\section{b. Presentation Session}

It was divided into five parts, namely: industry analysis and company profile, human resource plan, marketing plan, finance plan, and production plan. This was intended so that the participants could get insights about each department in specific. All materials were also delivered in Indonesian so that presentations were easier to understand, and points of our presentation could be obtained by the participants. In order to make explanations easier to understand, students also shared their experiences while running the business, from the constraints to the strategies that we implemented to 
develop the business, as real examples.

\section{c. Game Session}

Game session is used as ice breaking so they could refresh their minds and be more concentrate to listen to the materials to be delivered by the team (Figure 2). The games session was divided into 2, which the first game was "get to know each other", where participants and students would be given some time to get to know each other. The value of this game was that we wanted to convey that in the one team, they must know each other, not only from the surface or the name only, but also to know further about the other members. In addition, in the second session of the game, which was "mention it once", one team must mention A-Z, but one alphabet must not be mentioned simultaneously by several members. In this game we wanted to teach the participants to create synchronization inside the team as well as honing the participants' abilities in finding and implementing the right strategies.

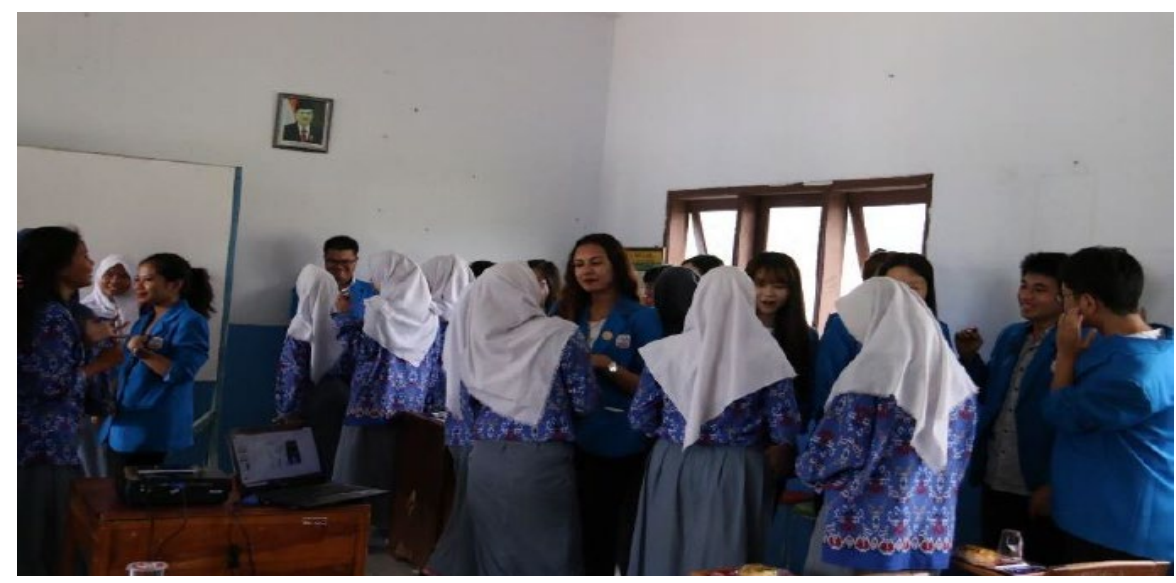

Figure 2. Game Session

\section{d. Appreciation and Photo Session}

To document the social community activities; and through the souvenirs and certificate that we provided, researcher hope that President University could be remembered by SMK Informatika Amanah Bangsa as the university that ever held a seminar or social community to the school (Figure 3). 


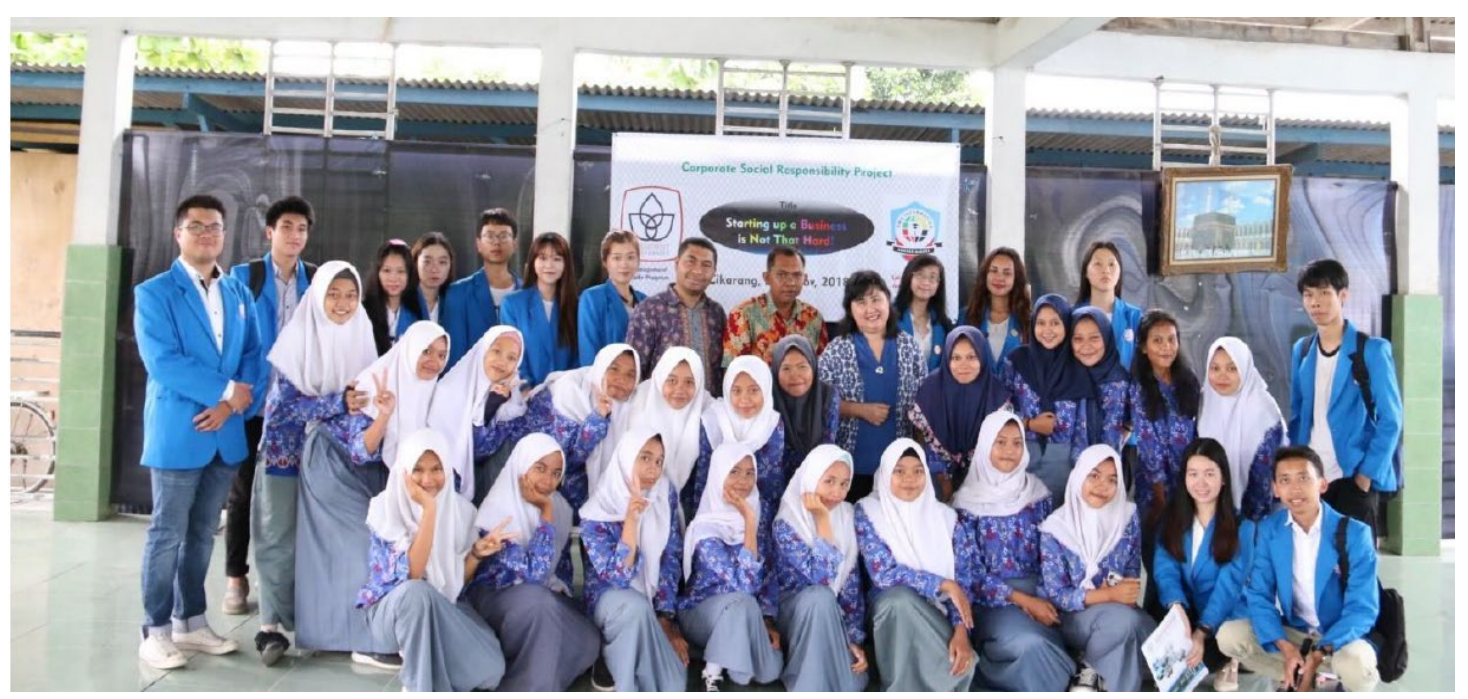

Figure 3. Foto Session of Participant and Instructor

\section{CONCLUSION AND RECOMMENDATION}

\section{a. Conclusion}

Overall, this activity did not find a significant obstacle or in other words, this activitity runs smoothly in accordance with the rundown and plans made, even at the end of there was still excess time. The objectives were also achieved where participants could get new insight and experience regarding entrepreneurship. With the activity object which was the vocational students, the possibility of working after graduation is greater than the senior high school students. By this social community activities, in which using the seminar methods with materials delivered through oral presentations, could provide new knowledge and encourage them to build their own business compared by relying on existing job vacancies only. This would later also contribute to Indonesia in reducing the existing unemployment rate, especially based on the previous research was greatly contributed by the vocational graduates.

\section{b. Recommendations}

The recommendation for the school are:

1) Organizing more seminars or training that can encourage and open students' minds about entrepreneurship,

2) Always updating the governance and facilities in accordance with the development of the era, so that the skills possessed by students also develop along with the current development,

3) Providing room with adequate presentation equipment such as projectors, plugs, tables for projectors, etc., so that the materials delivery process can be more effective. 
For the next social community activities, researchers do recommend that the team prepare all presentation slides and explanations in Indonesia language, except for certain important terms in business (e.g. Marketing Mix, BEP, etc.) to keep being delivered in English.

This event can be continued as a routine and continuous activities in the form of official cooperation. Therefore the program can be run better and be designed more deeply knowledge.

\section{REFERENCES}

Badan Pusat Statistik. (2018), www.bps.go.id.

Cahyu. (2017). Wirausaha Solusi Mengurangi Pengangguran. Retrieved from Liputan6.com: https://www.liputan6.com/news/read/3161378/wirausaha-solusimengurangi-pengangguran

Government Regulation of Republic of Indonesia Number 29 Year 1990 Regarding Middle Education. Retrieved from http://www. bphn.go.id /data/documents/90pp029.pdf

Komisi X. (2018). Tingginya Tingkat Pengangguran Lulusan SMK Dipertanyakan. Retrieved from http://www.dpr.go.id/berita/detail/id/22960/t/ Tingginya+Tingkat+Pengangguran $+\mathrm{L}$ ulusan+SMK+Dipertanyakan

Kuwado, F. J. (2018). Jumlah Entrepreneur di Indonesia Jauh di Bawah Negara Maju, Ini Kata Jokowi. Retrieved from Kompas.com: https://nasional.kompas.com/read/2018/04/05/17261391/jumlah-entrepreneur-diindonesia-jauh-di-bawah-negara-maju-ini-kata-jokowi

Putri, A.W. (2017). Salah Kaprah Lulusan SMK. Retrieved from Tirto.id: https://tirto.id/salah-kaprah-lulusan-smk-csAE

Ratnasari, E. D. (2018). BPS: Lulusan SMK Banyak Menganggur Sepanjang 2017. Retrieved from CNN Indonesia: https://www.cnnindonesia.com/gayahidup/20180223141505-282-278333/bps-lulusan-smk-banyak-menganggursepanjang-2017

Rusu, S., Isac, F., Curetanu, R., \& Csorba, L. (2012). Entrepreneurship and entrepreneur: A review of literature concepts. African Journal of Business Management, 6(10), 3570-3575. Retrieved from http://www.academicjournals.org/app/webroot/article/article1380871742_Rusu\%2 0et\%20al.pdf

Smith, J. A., \& Reid, G. C. (2000). What Makes A New Business Start-Up Successful? Small Business Economics, 14, 165-182. Retrieved from https://www.researchgate.net/publication/5158015_What_Makes_a_New_Busines s_Start-Up_Successful 